\begin{tabular}{|l|l|}
\hline Postprint Version & 1.0 \\
\hline Journal website & $\underline{\mathrm{http}: / / \mathrm{dx} . \text { doi.org/10.1007/s13187-011-0227-x }}$ \\
\hline Pubmed link & $\underline{\mathrm{http}: / / \text { www.ncbi.nlm.nih.gov/pubmed/21533850 }}$ \\
\hline DOI & $10.1007 / \mathrm{s} 13187-011-0227-\mathrm{x}$ \\
\hline
\end{tabular}

\title{
Use and Evaluation of an Individually Tailored Website for Counselees Prior to Breast Cancer Genetic Counseling
}

\author{
AkKe AlbadA $^{1}$, Margreet G. E. M. Ausems ${ }^{2}$, Roel OtTen ${ }^{1}$, Jozien M. Bensing ${ }^{1,3}$ And \\ SANDRA VAN DULMEN ${ }^{1}$
}

(1) NIVEL (Netherlands Institute for Health Services Research), P.O. Box 1568, 3500, BN, Utrecht, The Netherlands

(2) Department of Medical Genetics, University Medical Center Utrecht, Utrecht, The Netherlands

(3) Department of Health Psychology, Utrecht University, Utrecht, The Netherlands

\begin{abstract}
This article explores the use and evaluation of a pre-visit website which aims to prepare counselees who are the first in their family to request breast cancer genetic counseling. This website E-info gene ${ }^{\text {ca }}$ provides computer-tailored information and a blank question prompt sheet (QPS) on which counselees can formulate their questions for the consultation. The objectives of this study are: first, to assess which factors influence the use of E-info gene ${ }^{\text {ca }}$, including the duration of site and page views, the influence of topic sequence in the menu bar on the sequence of page views, and the relation between website use and the use of the QPS; second, to explore counselees' evaluations of E-info gene ${ }^{\text {ca }}$ and relations with counselee characteristics. User statistics were analyzed to describe duration of site and page views. Multivariate analyses were used to predict duration of web and page views, sequence of page views, QPS use, and site evaluations. Independent variables were sociodemographic background, disease status, psychological functioning, and information needs. All 101 counselees who were provided with a login accessed the website and spent, on average, $21 \mathrm{~min}$ viewing the website. Counselees affected with breast cancer spent more time on the website than unaffected counselees. Half of all page views were within the sequence of topics in the menu and older counselees, and those who made less use of the internet more often navigated according to the menu sequence than others. Having viewed information about why it is important to ask questions increased QPS use. Counselees who had higher information needs considered the information more helpful. This hospital-provided website for breast cancer genetic counselees was accessible and was evaluated positively, even concerning older counselees and those who had not searched the internet for information about hereditary cancer. Counselees might navigate hospital-provided websites more in line with the sequence of topics in the menu bar, than generally accessible health websites.
\end{abstract}


Albada, A., Ausems, M.G.E.M., Otten, R., Bensing, J.M., Dulmen, S. van. Use and evaluation of an individually tailored website for counselees prior to breast cancer genetic counseling. Journal of Cancer Education: 2011, 26(4), 670-681

\section{INTRODUCTION}

Breast cancer genetic counseling is available for individuals with a (family) history of breast cancer who wish to learn their own and/or their family's cancer risk. It is offered in cancer genetic centers by genetic counselors and comprises education about cancer (recurrence) risk, cancer prevention, and early detection with the aim of reducing morbidity and mortality [1]. The first visit consists of education about inheritance of hereditary breast cancer, possibilities for DNA testing, and psychosocial consequences for the counselee and relatives. However, as public knowledge of genetics is scarce [2,3], counselees who are the first in their family to request breast cancer genetic counseling (probands) are often unsure about what to expect [4, 5] or expect to be offered a DNA test independent of their disease status and risk profile [6]. Within the first consultation, counselees generally have a passive role, receiving large amounts of relatively standard information [7-10]. Consequently, after the first consultation, about one fifth of the counselees have unfulfilled needs regarding emotional matters and explanations about their cancer risk [11]. Consultations may become more effective if counselees voice their needs. To prepare counselees for this more active role, a website with pre-visit computer-tailored information and question prompt sheet, called E-info gene ${ }^{\text {ca }}$, was developed [12]. This website provided counselees with information about what to expect of genetic counseling. To avoid supplying counselees with large amounts of generic information not applicable to their specific situation, the information was computer-tailored to the individual based on counselees' medical and family history and information preference. Counselees could write questions for the consultation on the question prompt sheet (QPS).

Hospital-facilitated websites, like E-info gene ${ }^{\text {ca }}$, are integrated in patient care to better inform patients and provide ability to tailor information to patient characteristics, but little is known about how these websites are being used. Since tailored health information is increasingly delivered over the web [13], it is feasible to report usage data, i.e., the duration of site visit and the number of visited web pages as obtained from server $\log$ files or web-tracking services. Web-based information hereby overcomes an important limitation of printed materials [14], because the dosage is likely to affect outcome $[14,15]$. Dosage is increasingly reported for publicly accessible health websites $[16,17]$ but still poorly reported in studies of hospitalfacilitated [18] and computer-tailored [19] websites [14]. Consequently, user and website characteristics that may influence website use are scarcely studied. If more was known about these determinants, websites could be optimized to best engage their users, increase the dose and eventually the effects of the websites. The current study aims to untangle the factors that influence counselees' use and evaluation of the website E-info gene ${ }^{\text {ca }}$.

E-info gene ${ }^{\text {ca }}$ might be differently used than publicly accessible cancer websites. Breast cancer patients increasingly search the internet for health related information; estimates are between $42 \%[20,21]$ to $50 \%$ [22] in the USA and Canada and up to $71 \%$ in the Netherlands [23]. Young, higher educated women with high socioeconomic status most often used the internet to find cancer information [20, 21, 23]. Although patients find it difficult to judge reliability and relevance of information on the internet, few have the courage to discuss the information that they found with their physician $[21,23]$. Nonetheless, most patients view their health care professional as the most important source of information and prefer to receive additional information from a website provided by their hospital [23]. These websites might therefore be used by an even higher percentage of patients than publicly accessible websites.

Although there are guidelines about descriptiveness of tab labels and usability of navigation [24], little is known about the influence of sequence of topics in the menu bar on navigation patterns. Based on the primacy effect, one would expect highest recall of the information on the web pages that were viewed first [25]. Additionally, there is a tendency for information perceived as more important to be better recalled. It could therefore be useful to adjust the sequence of topics in the menu based on information needs.

However, this would only be worthwhile if individuals would navigate according to the given sequence of topics in the menu bar. In order to check for the influence of menu sequence, we varied the sequence of menu items in E-info gene ${ }^{\text {ca }}$ per counselee.

Use of a QPS in cancer consultations has shown to increase the number of patient questions and to empower patients to raise specific topics [26]. Counselee question asking can tailor the visit to individual needs and increase recall of information [27] and perceived personal control through better needs fulfillment $[11,28,29]$. However, few studies assessed how patients use a QPS [30]. Because most QPS interventions are print instead of web-based, it is generally unknown whether and which questions patients write down on the QPS, as only the questions that patients ask in the consultation can be assessed [26]. 
Albada, A., Ausems, M.G.E.M., Otten, R., Bensing, J.M., Dulmen, S. van. Use and evaluation of an individually tailored website for counselees prior to breast cancer genetic counselng. Journal of Cancer Education: 2011, 26(4), 670-681

Additionally, there are no studies of the relation between individuals' use of provided information and the topics of their questions. QPS have not been applied in genetic counseling so far. The results of the current study can thus help to shed light on the conditions under which a QPS might be used and about the use of a QPS within breast cancer genetic counseling.

Earlier studies have involved providing (non-tailored) computer-based pre-visit information to counselees in breast cancer genetic counseling and found positive counselee evaluations [31-33]. Based on these studies, some associations of evaluations with counselee characteristics might be expected. Counselees who never searched for information about hereditary cancer on the internet might find E-info gene ${ }^{\text {ca }}$ more useful than counselees who already searched the web. Additionally, we expect counselees with high information needs to evaluate E-info gene ${ }^{\text {ca }}$ more positively. And finally, as tailored information is intended to reach one specific person [34], it is more likely to be viewed as personally relevant [35, 36], to be read, and to be remembered [37-39]. Tailored as opposed to generic information about breast cancer genetic counseling has also been found to be more often perceived as the right amount of information [36]. Therefore, we expect that counselees perceive the information on E-info gene ${ }^{\mathrm{ca}}$ as personally relevant and not too much. This study will address the following research questions:

1. How is E-info gene ${ }^{\mathrm{ca}}$ used and which factors are related to this use?

(a) Which counselee characteristics are related to the duration of site and page views?

(b) What is the relation between topic sequence in the menu bar and sequence of page views?

(c) Is use of the QPS related to duration of site view and pages views?

2. How is E-info gene ${ }^{\mathrm{ca}}$ evaluated by counselees and are these evaluations associated with counselee characteristics?

\section{METHODS}

This study was conducted at the department of Medical Genetics of the University Medical Center Utrecht (UMCU). The study is approved by the medical ethical committee of this hospital. The department of Medical Genetics included consecutive new counselees from February 2008 to April 2010 [12]. Counselees were not eligible when they requested DNA testing because of an identified BRCA1/2 gene mutation in a relative. All counselees who were aged 18 years or older and who were the first of their first-degree family members to seek breast cancer genetic counseling were sent study information with their appointment letter. Ten counselees were not eligible because they lacked internet or email access. Counselees received a personal login for the baseline internet questionnaire by mail and email a week before their first consultation and an email or telephone reminder 2 days before the consultation. After completing this questionnaire, they received a link to the website E-info gene ${ }^{\text {ca }}$. Upon closing the website, counselees were asked to write their questions on the QPS and to complete an evaluation form about E-info gene ${ }^{\mathrm{ca}}$.

\section{Counselee Characteristics}

Counselee characteristics were assessed with the baseline questionnaire. These included counselees' year of birth, level of education, personal and family cancer history, and whether or not they had children. Counselees' preference for a certain level of detail in information was measured with a 10-point rating scale $[40,41]$ and was dichotomized into concise (score 1-5) and extensive information (score 6-10). Also, it was assessed whether the counselee considered risk reducing breast surgery. Additionally, the baseline questionnaire included a question about whether the counselee had searched for information about cancer and genetics on the internet. Counselees' information needs were assessed with the QUOTE-gene ${ }^{\mathrm{ca}}$, a counselee-based questionnaire [5]. All items were formulated as importance statements ("During counseling, the counselor should...") to be answered on a four-point scale, anchored by 1 "not important" and 4 "extremely important." An overall mean score was calculated. The baseline level of accurate knowledge about hereditary breast cancer was assessed with a seven-item scale [11, 29], the number of correct answers ranged from 0 to 7 . The four-item cancer worry scale was used [42] to assess frequency of worry about breast cancer in different settings during the past month, anchored by 1 "not at all" to 4 "a lot." 
Albada, A., Ausems, M.G.E.M., Otten, R., Bensing, J.M., Dulmen, S. van. Use and evaluation of an individually tailored website for counselees prior to breast cancer genetic counseling. Journal of Cancer Education: 2011, 26(4), 670-681

Levels of generalized state anxiety were assessed with the Dutch 10-item version of the State-Trait Anxiety Inventory [43, 44] as used in previous research in cancer genetic counseling [11].

An algorithm (included in Table 1) was developed to calculate the risk of being a mutation carrier based on the self-reported personal and family cancer history. This algorithm was based on the Dutch national guidelines on diagnostics for hereditary cancers [45]. A high risk of being a mutation carrier meant that there is a risk of $10 \%$ or more that a BRCA1/2 mutation is present in the counselee or an affected family member.

\section{[TABLE 1]}

\section{E-info Gene ${ }^{\text {ca }}$}

The development process of E-info gene ${ }^{\text {ca }}$ was elaborately described elsewhere [12]. This website provided counselees with tailored information about breast cancer genetic counseling. The menu bar was placed at the top of the webpage and covered the main topics; submenus were placed in the left panel. The five main topics represented the information needs factors of the QUOTE-gene ${ }^{\text {ca }}$ questionnaire [5]: the genetic counseling procedure, determination, and meaning of being carrier of mutation in a breast cancer gene, breast cancer risk, emotional consequences, and hereditary breast cancer. The main topics in the horizontal menu bar systematically varied in order. Figure 1 shows a screenshot of E-info gene ${ }^{\mathrm{ca}}$.

\section{[FIGURE 1]}

The information on E-info gene ${ }^{\text {ca }}$ was computer-tailored by adaptation to the individual counselee based on counselee characteristics [46, 47]: age, disease status, and whether the counselee had children [12]. Also, the website was tailored based on the counselee's risk of hereditary breast cancer based on self-reported personal and family cancer history; high-risk counselees received more information about being a carrier of a mutation on the breast cancer genes and screening options. Only counselees who considered risk-reducing breast surgery received information about this topic. Consequently, the number of web pages differed per counselee. Additionally, counselees received extensive or concise information on these web pages based on their preferred level of detail. Although counselees were informed about the tailoring through the study information, on E-info gene ${ }^{\mathrm{ca}}$ itself, the tailoring was hidden in the sense that the website did not show the name of the counselee nor referred to the fact that the information was computer-tailored.

The information at E-info gene ${ }^{\text {ca }}$ was supplemented with an online blank QPS, on which counselees could write questions for the consultation and print these. This QPS was introduced by the topic "In consultation," with advice about how best to communicate with the counselor. The QPS appeared as the first page of the evaluation form.

\section{User Statistics}

Usage of E-info gene ${ }^{\text {ca }}$ was recorded with the web tracking service SiteStat (Nedstat; NL) and contained all web page requests by date and time, duration of page views, and click paths. We related these user activity records to each respondent by use of the webpage URL that included the respondent number. The questions posed on the QPS were saved in an internet survey program. For research purposes, respondents could visit E-info gene ${ }^{\mathrm{ca}}$ only once, unless they received an email reminder including their personal link, which was sent when the counselee had not filled in the evaluation form.

\section{Question Prompt}

We performed a content analysis on the questions that counselees had written on the QPS. This content analysis was based on the items of the QUOTE-gene ${ }^{\text {ca }}$. The first $30 \%$ of the responses were coded independently by both the first (AA) and the last author (MA). Agreement between coders was $79 \%$. Disagreements were discussed and AA coded the remaining $70 \%$ of the responses.

\section{Counselees' Evaluation}

The evaluation form assessed whether counselees found the website neatly arranged, visually attractive, and clearly structured using a series of four-point Likert scales, with higher scores indicating greater satisfaction. Similarly, counselees were asked to indicate to what degree the information was useful, easy to understand, helpful for themselves, helpful for family and friends, confusing, upsetting, reassuring, reliable, timely, too much, and personally relevant. These items were based on evaluation of patient information by 
Albada, A., Ausems, M.G.E.M., Otten, R., Bensing, J.M., Dulmen, S. van. Use and evaluation of an individually tailored website for counselees prior to breast cancer genetic counseling. Journal of Cancer Education: 2011, 26(4), 670-681

Butow et al. [48]. Additionally, the evaluation form assessed whether counselees' family members or friends had read (a part of) E-info gene ${ }^{\mathrm{ca}}$.

\section{Statistical Analysis}

With regard to the first research question, we conducted multivariate regression analyses to explore the relations between counselee characteristics and duration of site visit. First, a multivariate regression analysis was conducted for duration of site visit with the counselee characteristics as independent variables: age, educational level, having children, cancer history, information needs (sum score of QUOTE-gene ${ }^{\mathrm{ca}}$ ), knowledge, breast cancer worry, and anxiety levels. Additionally, for each main topic, the duration of page views within this topic was calculated. We then conducted multivariate regression analyses on these variables with counselee characteristics and counselees' information need about this topic. Concerning research question $1 \mathrm{~b}$, we compared the sequence of page views with the menu sequence and conducted a multivariate regression analysis on the number of pages that were viewed within the given menu sequence. Independent variables were age, educational level, anxiety, breast cancer worry, and prior internet use. Regarding question $1 \mathrm{c}$, we conducted $\mathrm{t}$ tests and $\chi^{2}$ tests to check for associations of posing questions on the QPS with time spent on the website, having visited specific web pages, and counselee characteristics. Regarding the second research question, we conducted a MANOVA with the counselee's evaluations of the website as dependent variables and the counselee characteristics as independent variables. All analyses were conducted in SPSS 14.0.

\section{RESULTS}

One hundred one counselees were given a username and password to access the website E-info gene ${ }^{\mathrm{ca}}$. Their mean age was 42, ranging from 21 to 70 years of age. Most counselees $(71.3 \%)$ had children and $33.7 \%$ was higher educated (MSc/BSc; Table 1). Almost half of them (48.5\%) had a personal history of breast cancer and $43 \%$ was referred by their GP. One fourth (28\%) of counselees had suggested the referral themselves. Of the counselees, $62(62.6 \%)$ had not searched the internet for information about cancer and genetics. Twelve counselees (12.1\%) had searched the internet once and $25(25.3 \%)$ more than once.

\section{Website Use}

All 101 counselees accessed E-info gene ${ }^{\text {ca }}$. Most counselees (74.7\%) viewed E-info gene ${ }^{\text {ca }}$ once, and 24 counselees $(25.3 \%)$ had more than one session. In the latter case, the sum of the page views and durations was used for the analyses. Six counselees only visited the home page. The average duration of the website visit varied. All but one of the cases were between a minimum of $39 \mathrm{~s}$ and a maximum of $1 \mathrm{~h}$ and $36 \mathrm{~min}$. Additionally, there was one outlier of $4 \mathrm{~h}$ and $38 \mathrm{~min}$. The median duration including the outlier was $14 \mathrm{~min}$ and $40 \mathrm{~s}$, and the interquartile range (the difference between the third and first quartiles) was 25 min and $28 \mathrm{~s}$. The mean duration of site visit disregarding this outlier was $21 \mathrm{~min}$ and $5 \mathrm{~s} \mathrm{(SD} 19$ min and $53 \mathrm{~s}$ ). Analyses concerning the duration of page views were conducted disregarding the outlier.

\section{Page Views and Information Needs}

Counselees viewed on average 11 (SD 8.0) of all 19 informative web pages. They indicated the highest information needs on the topics of breast cancer risk and screening (Table 2). The topic of hereditary breast cancer was considered least important.

\section{[TABLE 2]}

The web pages that were viewed by almost all counselees were about expectations of genetic counseling and screening. Pages about DNA testing, hereditary breast cancer, and emotional consequences of genetic counseling were also viewed by a large majority. All these pages were the first page within the topic and were thus requested by clicking a link in the main menu. Pages that were requested by clicking a link in the sub menu in the left page margin were viewed by fewer counselees. For example, less than half of the respondents viewed the pages about the genetic counseling procedure and analysis of family history. Counselees viewed the web pages about inheritance, emotional consequences, and hereditary breast cancer longest. 
Albada, A., Ausems, M.G.E.M., Otten, R., Bensing, J.M., Dulmen, S. van. Use and evaluation of an individually tailored website for counselees prior to breast cancer genetic counseling. Journal of Cancer Education: 2011, 26(4), 670-681

\section{Sequence of Page Views}

On average, $50.7 \%$ (SD 31.2\%) of the page views were requested in accordance with the menu sequence. Almost half of the counselees $(47.5 \%)$ viewed $50 \%$ or more of the requested pages within the sequence of topics in the menu bar. Often, counselees started viewing the pages within the menu sequence and afterwards reread parts of the website.

\section{Question Prompt Sheet}

Of the counselees, $42(41.7 \%)$ formulated at least one question on the QPS. On average, they posed 3.1 questions (SD 1.1). Questions focused most often on screening options for self or children (20), the counselee's breast cancer risk (18), family members' breast cancer risk (16), indications for hereditary breast cancer (14), possibilities for DNA testing (13), and inheritance (6).

\section{Counselees' Evaluation}

Of all 101 counselees, 85 (84.2\%) evaluated the website on the evaluation form. All counselees considered the website clearly structured and neatly arranged and found the information useful (Table 3). Almost all counselees considered the information easy to understand, reliable (98.8\%), and helpful (95.2\%). Most respondents $(86.9 \%)$ considered the information useful for family and friends, while only $13(15.5 \%)$ counselees stated that one or more of their family members or friends viewed E-info gene ${ }^{\text {ca }}$. Almost a third $(28.9 \%)$ of the respondents did not find the information reassuring, and some thought it was upsetting (14.4\%). Some respondents did not consider the information personally relevant $(20.2 \%)$ or found the information too much $(9.6 \%)$.

\section{[TABLE 3]}

\section{Counselee Characteristics and Duration of Site Visit and Page Views}

Table 4 shows the outcomes of the regression analysis on total duration of website visit. The counselee characteristics explained $13 \%$ of the variance of the duration of site view. Counselees who had breast cancer spent more time on E-info gene ${ }^{\mathrm{ca}}(\beta=29 ; \mathrm{P}=0.04)$, and there was a trend towards increased duration of site visit by counselees who were more anxious $(\beta=0.25 ; \mathrm{P}=0.08)$ and by those who preferred concise information $(\beta=-.21 ; \mathrm{P}=.053)$.

\section{[TABLE 4]}

Additionally, regression analyses on duration of page visits within the main topics were conducted (Table 4). For "genetic counseling procedure," age and having children showed a significant positive relation to the duration of page views within this topic $(\beta=.33 ; \mathrm{P}=.02$ and $\beta=.33 ; \mathrm{P}=.01)$. Counselees with a high-risk profile for hereditary breast cancer received more information on most topics. For the topics of "being a carrier" and "breast cancer risk," this tailoring variable indeed predicted duration of page views $(\beta=.55 ; \mathrm{P}=.000$ and $\beta=.42 ; \mathrm{P}=.000$, respectively). Also, counselees preferring concise information spent more time on pages about emotional consequences than others $(\beta=-.23 ; \mathrm{P}=.04)$.

\section{Counselee Characteristics and Navigation}

Six counselees only visited the homepage. All six counselees had never searched the internet for information about cancer and genetics, which showed a trend towards a statistically significant difference with counselees who had viewed beyond the home $\left(\chi^{2}=3.81 ; \mathrm{df}=1 ; \mathrm{P}=.051\right)$. There was also a trend towards a statistically significant difference in age $\left(\chi^{2}=2.92 ; \mathrm{df}=1 ; \mathrm{P}=.09\right)$, and there was no significant difference in education $\left(\chi^{2}=.544 ; \mathrm{df}=1 ; \mathrm{P}=.46\right)$ between these groups. Counselees who were older more often navigated in accordance with the menu sequence $(\beta=-.24 ; \mathrm{P}=.02)$. Counselees who had searched the internet for information about cancer and genetics navigated less often in accordance within the menu sequence than those who had not searched the web $(\beta=-.244 ; \mathrm{P}=.02)$. High educational attainment $(\beta=$ $.06 ; \mathrm{P}=.60)$, anxiety $(\beta=-.099 ; \mathrm{P}=.511)$, and breast cancer worry $(\beta=.05 ; \mathrm{P}=.71)$ were not significantly related to navigation behavior.

\section{Counselee Characteristics and Use of the QPS}

Counselees who had used the QPS had spent more time on the website than others (23 min and $53 \mathrm{~s}$ vs. $17 \mathrm{~min}$ and $13 \mathrm{~s})$, but this difference was not statistically significant $(\mathrm{t}=1.67 ; \mathrm{P}=.10)$. However, 
Albada, A., Ausems, M.G.E.M., Otten, R., Bensing, J.M., Dulmen, S. van. Use and evaluation of an individually tailored website for counselees prior to breast cancer genetic counseling. Journal of Cancer Education: 2011, 26(4), 670-681

counselees who had viewed the web page "in consultation" about communication with their counselor had more often formulated questions on the QPS $\left(\chi^{2}=5.70 ; \mathrm{df}=1 ; \mathrm{P}=.02\right)$. Of the counselees who had viewed this page, $47.4 \%$ used the QPS, compared to $16.7 \%$ of those who had not viewed this page. Also, higher educated counselees used the QPS more often $\left(\chi^{2}=4.67 ; \mathrm{df}=1 ; \mathrm{P}=.03\right)$. Counselees who had written a question concerning DNA testing had viewed the pages about "being a carrier" including information about possibilities of DNA testing longer than others $(2$ min and $42 \mathrm{~s} \mathrm{vs.} 1$ min and $12 \mathrm{~s} ; \mathrm{t}=$ $2.48 ; \mathrm{P}=.02)$. This relationship was present neither for questions about screening and duration of page views within the topic of screening $(\mathrm{t}=-1.07 ; \mathrm{P}=.29)$ nor questions about prevalence and page views within this topic $(\mathrm{t}=-1.55 ; \mathrm{P}=.13)$.

\section{Counselee Characteristics and Website Evaluations}

Counselees who had higher information needs considered the information on the website E-info gene ${ }^{\text {ca }}$ more useful $(\mathrm{F}=4.49 ; \mathrm{P}=.04)$, helpful $(\mathrm{F}=8.11 ; \mathrm{P}=.006)$, reliable $(\mathrm{F}=6.86 ; \mathrm{P}=.01)$, and easier to understand $(\mathrm{F}=5.05 ; \mathrm{P}=.03)$ than counselees with lower information needs. Counselees with a higher risk of hereditary breast cancer had received more information about risks for mutation carriers on their tailored website and more often found the information upsetting $(\mathrm{F}=4.81 ; \mathrm{P}=.03)$. Counselees who had searched the web for cancer genetic information did consider the information on E-info gene ${ }^{\text {ca }}$ somewhat less useful for family and friends $(\mathrm{F}=3.35 ; \mathrm{P}=.07)$, but this was not statistically significant. Counselees with high levels of knowledge more often considered the website useful for family and friends $(\mathrm{F}=4.87 ; \mathrm{P}=.03)$ and less often considered the information too much, although not statistically significant $(\mathrm{F}=3.50 ; \mathrm{P}=.07)$. Age, having children, and disease status were not significant predictors of the website evaluations. All eight counselees who considered the information on E-info gene ${ }^{\text {ca }}$ too much had indicated to prefer extensive information on the baseline pre-tailoring questionnaire.

\section{DISCUSSION}

All counselees who were given access to E-info gene ${ }^{\text {ca }}$ did visit this innovative website that provides computer-tailored information and a question prompt sheet prior to the first breast cancer genetic counseling visit. Most counselees had not previously searched the internet for information about hereditary cancer. This hospital-provided website therefore showed increased accessibility compared to publicly available cancer genetics information on the internet. Similarly, Han et al. [49] found that less highly educated breast cancer patients and those lacking in information-seeking competence use online cancer information to the same or a greater degree if they are provided with a website by their hospital. Possibly, counselees were afraid of finding less reliable or irrelevant cancer genetic information on the internet, a common worry of patients [21, 23], and trusted the hospital-provided website more. On average, counselees spent 21 min on E-info gene ${ }^{\mathrm{ca}}$, which might be considered substantial compared to the genetic counseling consultations which last on average $45 \mathrm{~min}$ [7]. Moreover, visits to general health-related websites are mostly short, for example, the mean duration of visit of one of the most visited Dutch health-related website is $6 \mathrm{~min}$ [50]. These results support the suggestion that hospital-provided [23] and computer-tailored [35, 37] websites might engage counselees more, resulting in a high visit rate and increased length of visit compared to generally accessible health-related websites.

Regarding the first research question about determinants of the time spent on the website, we found that counselees who had breast cancer spent more time on the website than unaffected counselees. Other studies have found that affected counselees are more interested in the consequences for their family [5, 51], and this might have led them to spend more time on the website, mainly on the pages about inheritance of hereditary breast cancer and emotional consequences. The information on the website might thus be more vital to affected counselees. Also, counselees who were more anxious tended to have longer visits. Older counselees and those having children spent more time viewing pages about the genetic counseling procedure. Additionally, those preferring concise information needed more time on pages about emotional consequences. And counselees who were at high risk of hereditary breast cancer received tailored texts with more elaborate information about being a carrier and breast cancer risk, and they viewed these pages longer. In sum, increased age, having children, being affected with cancer, and receiving more tailored information were associated with increased duration of page views.

Additionally, our study indicated that patients might navigate a hospital-provided website more in accordance with the provided sequence of topics in the menu bar than generally accessible websites. On 
Albada, A., Ausems, M.G.E.M., Otten, R., Bensing, J.M., Dulmen, S. van. Use and evaluation of an individually tailored website for counselees prior to breast cancer genetic counseling. Journal of Cancer Education: 2011, 26(4), 670-681

average, almost half of all page views were in accordance with the menu sequence while the sequence of topics in E-info gene ${ }^{\text {ca }}$ varied per counselee. Users generally navigate a website in a less structured manner, i.e. searching the information needed [24]. Older users tend to rely on the provided structure more than younger users [52], and this was also found in the current study. Also, novice users of the internet for information about hereditary cancer more often followed the provided menu sequence. Usability guidelines for websites for older adults and novice internet users therefore advocate consistent and simple navigation structures with clear labels [53]. Although more research on navigation of hospital-provided websites might be needed, the current study suggests that sequence of topics in navigation structures of hospital-provided websites should be determined carefully. One approach is to apply the primacy effect which is theorized to increase recall of the topic that was read first [25]. When providing patients with restricted access health information, it would seem advisable to place the most important information first in the navigation bar or to computer-tailor the topic sequence based on the information needs.

Counselees who used the QPS to write questions for the consultation had more often viewed the web page about how to communicate with their counselor than others. This web page provided the advice to ask questions and to raise concerns in order to have ones information needs fulfilled. This finding suggests that counselees need to be motivated to write down their own questions, and this advice should be more accessible and might best be placed at the homepage of future websites that include a QPS. Only half of the counselees wrote down questions, which is comparable to the findings of Jones et al. with a blank QPS for cancer patients undergoing radiotherapy [54]. A study of oncology outpatients found higher QPS use, three fourths of all patients [30], and the advice about why to use the QPS might explain this higher uptake. Higher educated counselees used the QPS more often than those less highly educated. Lower educated counselees might have had more difficulty with formulating their questions or alternatively might have been less assertive in requesting the information they needed. In most other studies [26], the QPS used has contained example questions, which was not the case in this study because we did not want to influence counselees in which topics to raise. However, provision of example questions about genetic counseling might prompt for topics $[55,56]$ and thereby increase QPS use, also by those less highly educated.

With regard to the second research question, we found that counselees evaluated E-info gene ${ }^{\mathrm{ca}}$ very positively and counselees with high information needs considered the website most useful. This result was expected as the information on the website can fulfill information needs [5]. Contrary to our expectation, counselees who had searched the web for cancer genetic information did not find the website less useful for themselves but did find it somewhat less useful for friends and family. Possibly, they had already shared general information from the internet with their friends and family. Furthermore, most counselees considered the information personally relevant, which is consistent with the idea of increased personal relevance through computer tailoring to individual characteristics [37]. However, still $20 \%$ of the counselees did not perceive the information personally relevant. This might be due to incongruity of the information on the website with their beliefs about their risk or possibilities for DNA testing. According to the Theory of Cognitive Dissonance, high levels of dissonance are likely to result in a rejection of the message and the source [57]. Additionally, the tailoring on the preferred extensiveness of information appeared somewhat problematic. Consistent with earlier findings [36], the majority of counselees preferred extensive information and thus received the extensive texts. However, more than $10 \%$ of these counselees considered the information at E-info gene ${ }^{\mathrm{ca}}$ too much. A minority of the counselees might thus have difficulty processing extensive texts while at the same time preferring to receive extensive information. Finally, some counselees considered the information upsetting, especially those at high risk of hereditary breast cancer who had therefore received more information about risks for carriers on their tailored website. This is not an unexpected reaction since this information can be threatening, and unnecessary worries can be corrected during the consultation [11].

\section{Strengths and Limitations}

Strength of this study is that respondents were representative for breast cancer genetic counselees in age, education, and disease history [11]. There are some limitations. First, the study setting might have slightly increased the visit rates. However, it might also have decreased the number of site visits per counselee because most counselees could only access E-info gene ${ }^{\mathrm{ca}}$ once and only during the week prior to their first visit. This might also explain why few counselees shared information with family members, while Jones et al. found that cancer patients were likely to share tailored cancer information with their family [35]. Future 
Albada, A., Ausems, M.G.E.M., Otten, R., Bensing, J.M., Dulmen, S. van. Use and evaluation of an individually tailored website for counselees prior to breast cancer genetic counseling. Journal of Cancer Education: 2011, 26(4), 670-681

study should point out whether counselees' use of a pre-visit website differs outside of a study context. Second, the duration of page views could possibly be underestimated due to printing. We only provided a print facility for the QPS and not for other web pages of E-info gene ${ }^{\mathrm{ca}}$. Nonetheless, it is possible that counselees have printed web pages and read information from print. On the other hand, the duration of page views might be overestimated due to interferences, e.g., pouring a cup of tea. These under- and overestimations are inherent to user activity data. Third, some respondents only viewed the homepage or pages in the main menu. These users might not be at ease with using a website and might not know how to use the sub menu in the left margin of the web pages. Although the navigation structure of E-info gene ${ }^{\text {ca }}$ was simple, further usability testing might help to improve the website for novice internet users.

The current paper has shed light on the use of E-info gene ${ }^{\mathrm{ca}}$, a website aiming to better prepare counselees for breast cancer genetic counseling. Further study should indicate whether this use of E-info gene ${ }^{\text {ca }}$ contributes to increasing counselees' realistic expectations and participation in the genetic counseling consultation and post-counseling knowledge of hereditary breast cancer and perceived personal control. These effects are currently being evaluated in an RCT that is registered in the Dutch Trial Register (ISRCTN82643064) and results will be published in due course.

\section{Acknowledgements}

We are grateful to Ms. A. Wallet, secretary of the department of Medical Genetics of the UMCU, and Ms. D. Saya, secretary of Nivel, for organizing practicalities of the study. Also, we thank all counselees who participated in this research. This study was funded by the Dutch Cancer Society (Nivel 2006-3469).

\section{REFERENCES}

1. Biesecker BB (2001) Goals of genetic counseling. Clin Genet 60:323-330

2. Henneman L, Timmermans DR, Van der Wal G (2004) Public experiences, knowledge and expectations about medical genetics and the use of genetic information. Community Genet 7:33-43

3. Morren M, Rijken M, Baanders AN, Bensing J (2007) Perceived genetic knowledge, attitudes towards genetic testing, and the relationship between these among patients with a chronic disease. Patient Educ Couns 65:197-204

4. Hallowell N, Murton F, Statham H, Green JM, Richards MPM (1997) Women's need for information before attending genetic counselling for familial breast or ovarian cancer: a questionnaire, interview, and observational study. Br Med J 314:281-283

5. Pieterse A, Van Dulmen S, Ausems M, Schoemaker A, Beemer F, Bensing J (2005) QUOTE-gene ${ }^{\text {ca. }}$ development of a counselee-centered instrument to measure needs and preferences in genetic counseling for hereditary cancer. Psychooncology 14:361-375

6. Metcalfe A, Werrett J, Burgess L, Clifford C (2007) Psychosocial impact of the lack of information given at referral about familial risk for cancer. Psychooncology 16:458-465

7. Pieterse AH, Van Dulmen AM, Ausems MGEM, Beemer FA, Bensing JM (2005) Communication in cancer genetic counselling: does it reflect counselees' pre-visit needs and preferences? $\mathrm{Br} \mathrm{J}$ Cancer 92:1671-1678

8. Meiser B, Irle J, Lobb E, Barlow-Stewart K (2008) Assessment of the content and process of genetic counseling: a critical review of empirical studies. J Genet Couns 17:434-451

9. Butow P, Lobb E (2004) Analyzing the process and content of genetic counseling in familial breast cancer consultations. J Genet Couns 13:403-424 
Albada, A., Ausems, M.G.E.M., Otten, R., Bensing, J.M., Dulmen, S. van. Use and evaluation of an individually tailored website for counselees prior to breast cancer genetic counseling. Journal of Cancer Education: 2011, 26(4), 670-681

10. Ellington L, Roter D, Dudley WN, Baty BJ, Upchurch R, Larson S, Wylie JE, Smith KR, Botkin JR (2005) Communication analysis of BRCA1 genetic counseling. J Genet Couns 14:377-386

11. Pieterse AH, Ausems MGEM, Van Dulmen AM, Beemer FA, Bensing JM (2005) Initial cancer genetic counseling consultation: change in counselees' cognitions and anxiety, and association with addressing their needs and preferences. Am J Med Genet A 137:27-35

12. Albada A, Van Dulmen S, Otten R, Bensing JM, Ausems MGEM (2009) Development of E-info gene(ca): a website providing computer-tailored information and question prompt prior to breast cancer genetic counseling. J Genet Couns 18:326-338

13. Lustria ML, Cortese J, Noar SM, Glueckauf RL (2009) Computer-tailored health interventions delivered over the web: review and analysis of key components. Patient Educ Couns 74:156-173

14. Wantland DJ, Portillo CJ, Holzemer WL, Slaughter R, McGhee EM (2004) The effectiveness of Webbased vs. non-Web-based interventions: a meta-analysis of behavioral change outcomes. J Med Internet Res 6:e40

15. Nguyen HQ, Carrieri-Kohlman V, Rankin SH, Slaughter R, Stulbarg MS (2004) Internet-based patient education and support interventions: a review of evaluation studies and directions for future research. Comput Biol Med 34:95-112

16. Proudfoot J, Parker G, Hyett M, Manicavasagar V, Smith M, Grdovic S, Greenfield L (2007) Next generation of self-management education: web-based bipolar disorder program. Aust N Z J Psychiatry 41:903-909

17. Tian H, Brimmer DJ, Lin JM, Tumpey AJ, Reeves WC (2009) Web usage data as a means of evaluating public health messaging and outreach. J Med Internet Res 11:e52

18. Revere D, Dunbar PJ (2001) Review of computer-generated outpatient health behavior interventions: clinical encounters "in absentia". J Am Med Inform Assoc 8:62-79

19. Albada A, Ausems MGEM, Bensing JM, Van Dulmen S (2009) Tailored information about cancer risk and screening. Patient Educ Couns 77:155-171

20. Fogel J, Albert SM, Schnabel F, Ditkoff BA, Neugut Al (2002) Use of the internet by women with breast cancer. J Med Internet Res 4:E9

21. Pereira JL, Koski S, Hanson J, Bruera ED, Mackey JR (2000) Internet usage among women with breast cancer: an exploratory study. Clin Breast Cancer 1:148-153

22. Chen X, Siu LL (2001) Impact of the media and the internet on oncology: survey of cancer patients and oncologists in Canada. J Clin Oncol 19:4291-4297

23. Van de Poll-Franse LV, van Eenbergen MC (2008) Internet use by cancer survivors: current use and future wishes. Support Care Cancer 16:1189-1195

24. U.S. Department of Health and Human Services, U.S. General Services Administration (2008) Research-based web design \& usability guidelines. U.S Department of Health and Human Services, Washington, DC 
Albada, A., Ausems, M.G.E.M., Otten, R., Bensing, J.M., Dulmen, S. van. Use and evaluation of an individually tailored website for counselees prior to breast cancer genetic counseling. Journal of Cancer Education: 2011, 26(4), 670-681

25. Ley P (1979) Memory for medical information. Br J Soc Clin Psychol 18:245-255

26. Dimoska A, Tattersall MHN, Shepherd H, Kinnersley P (2008) Can a "Prompt List" empower cancer patients to ask relevant questions? Cancer 113:225-237

27. Van der Meulen N, Jansen J, Van Dulmen S, Bensing J, van Weert J (2008) Interventions to improve recall of medical information in cancer patients: a systematic review of the literature. Psychooncology $17: 857-868$

28. Fischer M, Visser A, Voerman B, Garssen B, Van den Andel G, Bensing J (2006) Treatment decision making in prostate cancer: patients' participation in complex decisions. Patient Educ Couns 63:308313

29. Pieterse AH, Dulmen AMV, Beemer FA, Bensing JM, Ausems MGEM (2007) Cancer genetic counseling: communication and counselees' post-visit satisfaction, cognitions, anxiety, and needs fulfillment. J Genet Couns 16:85-96

30. Wells T, Falk S, Dieppe P (2004) The patients' written word: a simple communication aid. Patient Educ Couns 54:197-200

31. Green JM, Fost N (1997) An interactive computer program for educating and counseling patients about genetic susceptibility to breast cancer. J Cancer Educ 12:204-208

32. Green MJ, Biesecker BB, McInervey AM, Mauger D, Fost N (2001) An interactive computer program can effectively educate patients about genetic testing for breast cancer susceptibility. Am J Med Genet 103:16-23

33. Green MJ, Peterson SK, Baker MW, Friedman LC, Harper GR, Rubinstein WS, Peters JA, Mauger DT (2005) Use of an educational computer program before genetic counseling for breast cancer susceptibility: effects on duration and content of counseling sessions. Genet Med 7:221-229

34. Kreuter MW, Strecher VJ, Glassman B (1999) One size does not fil all: the case for tailoring print materials. Ann Behav Med 21:276-283

35. Jones RB, Pearson J, Cawsey AJ, Bental D, Barrett A, White J, White CA, Gilmour WH (2006) Effect of different forms of information produced for cancer patients on their use of the information, social support, and anxiety: randomised trial. BMJ 332:942-948

36. Skinner CS, Schildkraut JM, Berry D, Calingaert B, Marcom PK, Sugarman J, Winer EP, Iglehart JD, Futreal PA (2002) Pre-counseling education materials for BRCA testing: does tailoring make a difference? Genet Test 6:93-105

37. Kreuter MW, Wray RJ (2003) Tailored and targeted health communication: strategies for enhancing information relevance. Am J Health Behav 27:S227-S232

38. Walters ST, Wright JA, Shegog R (2006) A review of computer and Internet-based interventions for smoking behavior. Addict Behav 31:264-277

39. Brug J, Oenema A, Campbell M (2003) Past, present, and future of computer-tailored nutrition education. Am J Clin Nutr 77:1028S-1034S 
Albada, A., Ausems, M.G.E.M., Otten, R., Bensing, J.M., Dulmen, S. van. Use and evaluation of an individually tailored website for counselees prior to breast cancer genetic counseling. Journal of Cancer Education: 2011, 26(4), 670-681

40. Cassileth BR, Zupkis RV, Sutton-Smith K, March V (1980) Information and participation preferences among cancer patients. Ann Intern Med 92:832-836

41. Zandbelt LC, Smets EM, Oort FJ, Godfried MH, de Haes HC (2006) Determinants of physicians' patient-centred behaviour in the medical specialist encounter. Soc Sci Med 63:899-910

42. Lerman C, Trock B, Rimer BK, Boyce A, Jepson C, Engstrom PF (1991) Psychological and behavioral implications of abnormal mammograms. Ann Intern Med 114:657-661

43. Spielberger CD (1983) Manual of the state-trait anxiety inventory. Consulting Psychologists Press, Palo Alto

44. Van der Ploeg HM, Defares PB, Spielberger CD (1980) Manual of the Dutch version of the state trait anxiety inventory [Handleiding bij de Zelfbeoordelings Vragenlijst (ZBV)]. Swets and Zeitlinger, Lisse

45. STOET, Association Clinical Genetics Netherlands, Working group Clinical Oncogenetics (2005) Hereditary tumors: Guidelines for diagnostics and prevention [Erfelijke tumoren: Richtlijnen voor diagnostiek en preventie].

46. Dijkstra A (2008) The psychology of tailoring. Ingredients in computer-tailored persuasion. Soc Person Psychol Comp 2:765-784

47. Hawkins RP, Kreuter M, Resnicow K, Fishbein M, Dijkstra A (2008) Understanding tailoring in communicating about health. Health Educ Res 23:454-466

48. Butow P, Devine R, Boyer M, Pendlebury S, Jackson M, Tattersall MH (2004) Cancer consultation preparation package: changing patients but not physicians is not enough. J Clin Oncol 22:4401-4409

49. Han JY, Wise M, Kim E, Pingree R, Hawkins RP, Pingree S, McTavish F, Gustafson DH (2010) Factors associated with use of interactive cancer communication system: an application of the comprehensive model of information seeking. J Comput-Mediat Commun 15:367-388

50. Colijn JJ (2010) Use and appreciation of Kiesbeter.nl in the year of 2009 [Gebruik en waardering van Kiesbeter.nl in 2009]. National Institute for Public Health and Environment, Utrecht

51. Julian-Reynier $C J$, Eisinger $F$, Chabal F, Aurran $Y$, Bignon $Y J$, Noguès $C$, Machelard-Roumagnac $M$, Maugard C, Vennin P, Sobol H (1998) Cancer genetic clinics: why do women who already have cancer attend? Eur J Cancer 34:1549-1553

52. Meyer B, Sit RA, Spaulding VA, Mead SE, Walker N (1997) Age group differences in world wide web navigation. $\mathrm{CHI} 97$ Electronic Publications: Late-Breaking/Short Talks

53. Zaphiris P, Kurniawan S, Ghiawadwale M (2010) A systematic approach to the development of research-based web design guidelines for older people. Univ Access Inf Soc 6:59-75

54. Jones R, Pearson J, McGregor S, Barrett A, Harper GW, Atkinson JM, Cawsey AJ, McEwen J (2002) Does writing a list help cancer patients ask relevant questions? Patient Educ Couns 47:369-371

55. Davison BJ, Degner LF (2002) Feasibility of using a computer-assisted intervention to enhance the way women with breast cancer communicate with their physicians. Cancer Nurs 25:417-424 
Albada, A., Ausems, M.G.E.M., Otten, R., Bensing, J.M., Dulmen, S. van. Use and evaluation of an individually tailored website for counselees prior to breast cancer genetic counseling. Journal of Cancer Education: 2011, 26(4), 670-681

56. Brown R, Butow PN, Boyer MJ, Tattersall MHN (1999) Promoting patient participation in the cancer consultation: evaluation of a prompt sheet and coaching in question-asking. Br J Cancer 80:242-248

57. Festinger L (1962) A theory of cognitive dissonance. Stanford University Press, Stanford

\section{[TABLES]}

$J$ Lanc Eauc

Table 1 Respondent characteristics $(N=101)$

\begin{tabular}{|c|c|c|c|c|}
\hline & Number & Percent & Range & Mean (SD) \\
\hline Age $(\text { years })^{\mathrm{a}}$ & & - & $21-70$ & $42.0(11.3)$ \\
\hline Children (having children) ${ }^{a}$ & 72 & 71.3 & & \\
\hline \multicolumn{5}{|l|}{ Educational attainment } \\
\hline$<$ High school level & 1 & 1.0 & - & - \\
\hline High school/secondary education & 35 & 34.7 & & \\
\hline Middle vocational education & 31 & 30.7 & - & - \\
\hline University (MSc/BSc)/higher vocational education (BSc) & 34 & 33.7 & - & - \\
\hline \multicolumn{5}{|l|}{ Referral pathway } \\
\hline GP & 43 & 43.0 & & \\
\hline Specialist consultant UMC & 26 & 26.0 & & \\
\hline Specialist consultant peripheral hospital & 31 & 31.0 & & \\
\hline \multicolumn{5}{|l|}{ Initiative for referral } \\
\hline Counselee & 28 & 28.0 & & \\
\hline Both counselee and physician & 44 & 44.0 & & \\
\hline Consultant & 18 & 18.0 & & \\
\hline GP & 4 & 4.0 & & \\
\hline Personal history of breast cancer (affected) ${ }^{a}$ & 49 & 48.5 & - & - \\
\hline Probability of being mutation carrier (high) ${ }^{\mathrm{ab}}$ & 45 & 44.6 & - & - \\
\hline Considering risk reducing breast surgery (yes) ${ }^{a}$ & 5 & 5.0 & - & - \\
\hline Information preference (extensive) ${ }^{a}$ & 90 & 89.1 & - & - \\
\hline Information needs (QUOTE gene ${ }^{\mathrm{ca}}$ ) $(1-4)$ & - & - & $2.3-4.0$ & $3.2(.38)$ \\
\hline Accurate knowledge (1-7) & - & - & $2-7$ & $4.7(1.6)$ \\
\hline Breast cancer worry $(1-4)$ & - & - & $1.0-3.5$ & $1.8(0.6)$ \\
\hline Anxiety $(10-40)$ & - & - & $10.0-39.0$ & $19.9(5.9)$ \\
\hline
\end{tabular}

${ }^{a}$ Variables used to tailor the information on E-info gene ${ }^{\text {ca }}$

${ }^{\mathrm{b}}$ Algorithm for this tailoring variable: IF (bc affected AND age at diagnosis $\leq 40$ ) OR (bc affected AND oc affected) OR (bc affected AND first second degree family members affected with oc) OR (number of first degree family members affected with bc $>1$ ) OR (number of first degree family members affected with oc $\geq 1$ ) OR (first/second degree family members affected with bc AND first/second degree family members affected with oc) OR (bilateral bc AND 1st diagnosis at age <50) OR (oc affected AND first/second degree family members affected with bc): probability=high 
Albada, A., Ausems, M.G.E.M., Otten, R., Bensing, J.M., Dulmen, S. van. Use and evaluation of an individually tailored website for counselees prior to breast cancer genetic counseling. Journal of Cancer Education: 2011, 26(4), 670-681

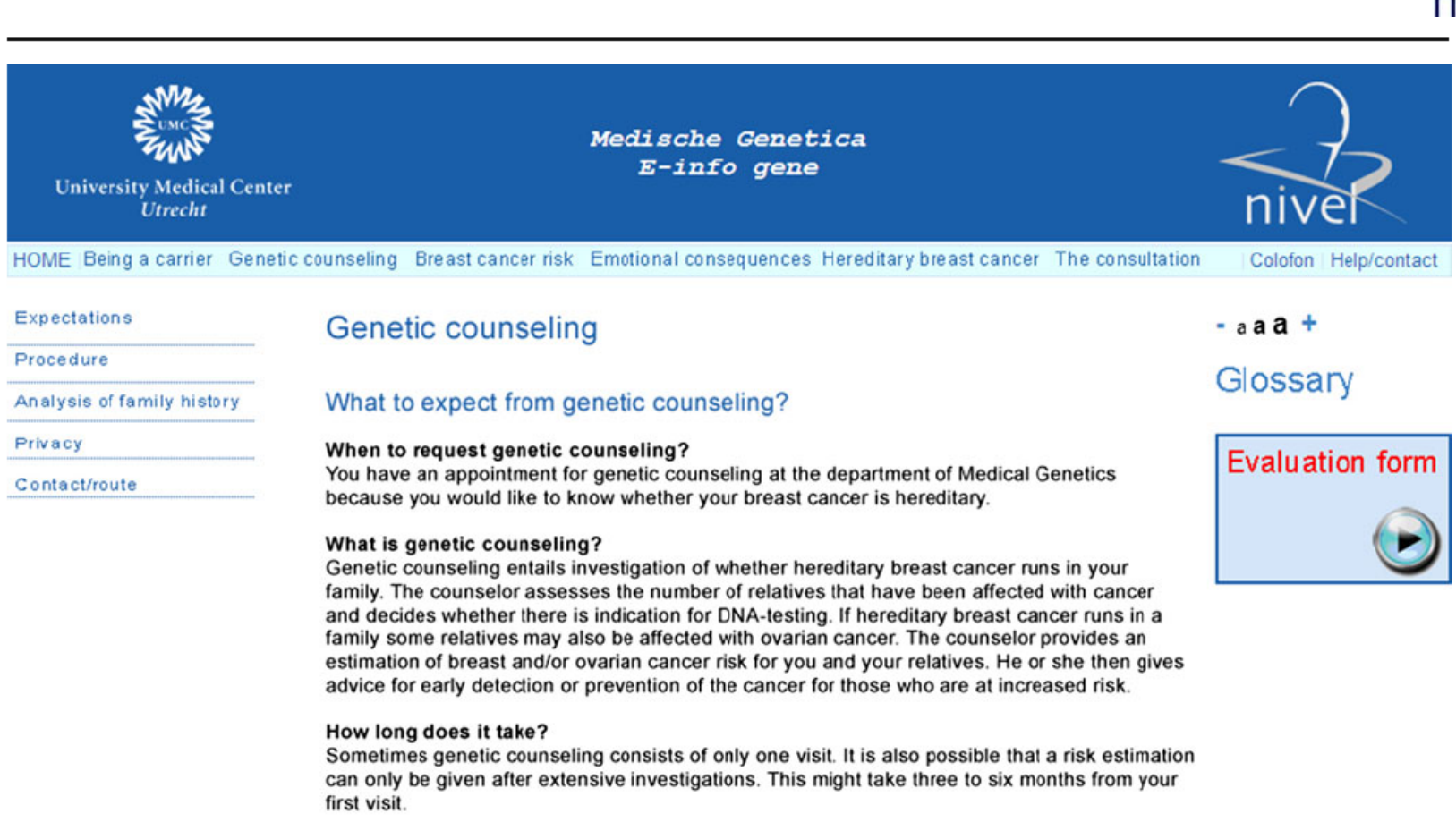

Fig. 1 Screenshot of the website E-info gene ${ }^{\mathrm{ca}}$ (translated from Dutch), main topic: Genetic counseling, web page: What to expect from genetic counseling 
Albada, A., Ausems, M.G.E.M., Otten, R., Bensing, J.M., Dulmen, S. van. Use and evaluation of an individually tailored website for counselees prior to breast cancer genetic counseling. Journal of Cancer Education: 2011, 26(4), 670-681

Table 2 Counselees' information needs, selection of web pages, and duration of page views $(N=101)$

\begin{tabular}{|c|c|c|c|c|c|}
\hline \multicolumn{2}{|l|}{ Main topics } & \multirow{2}{*}{$\begin{array}{l}\text { Information } \\
\text { need mean }(\mathrm{SD})^{\mathrm{a}}\end{array}$} & \multirow{2}{*}{$\begin{array}{l}\text { Counselees selecting } \\
\text { web page }^{\mathrm{b}}(\%)\end{array}$} & \multirow{2}{*}{$\begin{array}{l}\text { Average number } \\
\text { of page views }{ }^{\mathrm{b}, \mathrm{c}}\end{array}$} & \multirow{2}{*}{$\begin{array}{l}\text { Average time } \\
\text { per page }(\mathrm{m}: \mathrm{s})^{\mathrm{d}}\end{array}$} \\
\hline & Topics of web pages & & & & \\
\hline Home & & - & 100 & 3.55 & $4: 53(7: 28)$ \\
\hline \multirow[t]{6}{*}{ Genetic counseling } & & $3.2(.46)$ & & & $3: 32(4: 48)$ \\
\hline & Expectations & $3.0(.62)$ & 90.1 & 1.91 & $1: 32(2: 43)$ \\
\hline & Procedure & $3.2(.60)$ & 43.6 & 0.66 & $1: 39(1: 30)$ \\
\hline & Analysis of family history & $3.2(.53)$ & 40.6 & 0.46 & $0: 49(0: 42)$ \\
\hline & Privacy & - & 34.7 & 0.47 & $0: 57(1: 32)$ \\
\hline & Contact/route & - & 33.7 & 0.42 & $1: 09(4: 26)$ \\
\hline \multirow[t]{4}{*}{ Being a carrier } & & $3.3(.47)$ & & & $1: 48(2: 02)$ \\
\hline & DNA test & $3.2(.62)$ & 85.1 & 1.56 & $1: 37(1: 49)$ \\
\hline & Being a carrier ${ }^{\mathrm{e}}$ & $3.4(.56)$ & 24.4 & 0.40 & $1: 31(1: 39)$ \\
\hline & Societal consequences ${ }^{\mathrm{e}, \mathrm{f}}$ & - & 11.3 & 0.18 & $0: 02(-)$ \\
\hline \multirow[t]{5}{*}{ Breast cancer risk } & & $3.5(.47)$ & & & $1: 45(2: 34)$ \\
\hline & Screening & $3.5(.54)$ & 88.1 & 1.82 & $1: 27(2: 04)$ \\
\hline & Risk reducing breast surgery ${ }^{\mathrm{e}, \mathrm{g}}$ & - & $25.0(\mathrm{n}=1)$ & 0.50 & $1: 06(-)$ \\
\hline & Ovarian cancer risk ${ }^{\mathrm{h}}$ & - & 28.9 & 0.42 & $2: 02(1: 13)$ \\
\hline & Increased risk ${ }^{\mathrm{e}, \mathrm{g}}$ & - & 0 & 0 & - \\
\hline \multirow[t]{3}{*}{ Emotional consequences } & & $3.2(.54)$ & & & $2: 56(7: 09)$ \\
\hline & Genetic counseling & $3.2(.60)$ & 83.9 & 1.52 & $2.58(7: 19)$ \\
\hline & Support & - & 33.7 & .45 & $0.25(0: 30)$ \\
\hline \multirow[t]{4}{*}{ Hereditary breast cancer } & & $2.8(.54)$ & & & $4: 58(6: 28)$ \\
\hline & Hereditary breast cancer & $2.6(.63)$ & 85.1 & 1.76 & $2: 57(4: 41)$ \\
\hline & Inheritance $^{\mathrm{i}}$ & $3.3(.56)$ & 35.5 & 0.54 & $3: 38(3: 45)$ \\
\hline & What are genes ${ }^{j}$ & - & 33.3 & 0.40 & $1: 46(2: 41)$ \\
\hline \multirow[t]{3}{*}{ The consultation } & & - & & & $2: 42(3: 56)$ \\
\hline & In consultation & - & 81.2 & 1.34 & $2: 10(3: 35)$ \\
\hline & The counselors & - & 25.7 & 0.33 & $1: 37(2: 40)$ \\
\hline Word list & & - & 16.8 & 0.28 & $0: 58(0: 56)$ \\
\hline Help & & - & 5.9 & 0.05 & $2: 08(4: 25)$ \\
\hline Colophon & & - & 5.0 & 0.0 & $0: 09(0: 10)$ \\
\hline
\end{tabular}

$m$ minutes; $s$ seconds

${ }^{\text {a }}$ Only available for the main topics and for web pages conceming QUOTE-gene ${ }^{\text {ca }}$ items

${ }^{b}$ Of counselees who received a page on this topic in their tailored website

${ }^{\mathrm{c}}$ Immediate subsequent double requests were counted as one

${ }^{\mathrm{d}}$ If page was requested

${ }^{\mathrm{e}}$ Only for high-risk counselees

${ }^{\mathrm{f}}$ Only for counselees unaffected with breast cancer

${ }^{g}$ Only for counselees considering risk reducing breast surgery

${ }^{\mathrm{h}}$ Only for counselees at high risk and/or with first-degree family members with ovarian cancer

${ }^{i}$ Only for counselees at high risk and/or preferring extensive information

${ }^{\mathrm{j}}$ Only for counselees preferring extensive information 
Table 3 Counselees' ratings of E-info gene ${ }^{\text {ca }}\left(N=85^{\mathrm{a}}\right)$

\begin{tabular}{lcc}
\hline & \multicolumn{2}{l}{ (Totally) agree } \\
\cline { 2 - 3 } & $n$ & $\%$ \\
\hline The website was... & & \\
Neatly arranged & 84 & 100 \\
Clearly structured & 84 & 100 \\
Visually attractive & 78 & 95.1 \\
The information on the website was... & & \\
Useful & 85 & 100 \\
Easy to understand & 83 & 98.8 \\
Reliable & 83 & 98.8 \\
Helpful & 80 & 95.2 \\
Timely & 78 & 94.0 \\
Helpful to family and friends & 73 & 86.9 \\
Personally relevant & 67 & 79.8 \\
Reassuring & 59 & 71.1 \\
Upsetting & 12 & 14.4 \\
Too much & 8 & 9.6 \\
Confusing & 7 & 8.5 \\
\hline
\end{tabular}

${ }^{\text {a }}$ Missing values varied from 0 to 3 
Albada, A., Ausems, M.G.E.M., Otten, R., Bensing, J.M., Dulmen, S. van. Use and evaluation of an individually tailored website for counselees prior to breast cancer genetic counseling. Journal of Cancer Education: 2011, 26(4), 670-681

Table 4 Predictors of counselees' duration of site visit and page views per main topic, results of regression analyses $(N=100)$

\begin{tabular}{|c|c|c|c|c|c|c|c|c|c|c|c|c|}
\hline \multirow[t]{3}{*}{ Predictors } & \multicolumn{12}{|c|}{ Duration of page views within the main topic } \\
\hline & \multicolumn{2}{|c|}{$\begin{array}{l}\text { Duration of } \\
\text { website visit }\end{array}$} & \multicolumn{2}{|c|}{$\begin{array}{l}\text { Genetic } \\
\text { counseling } \\
\text { procedure }\end{array}$} & \multicolumn{2}{|c|}{ Being a carrier } & \multicolumn{2}{|c|}{$\begin{array}{l}\text { Breast } \\
\text { cancer risk }\end{array}$} & \multicolumn{2}{|c|}{$\begin{array}{l}\text { Emotional } \\
\text { consequences }\end{array}$} & \multicolumn{2}{|c|}{$\begin{array}{l}\text { Hereditary } \\
\text { breast } \\
\text { cancer }\end{array}$} \\
\hline & $\beta$ & $P$ & $\beta$ & $P$ & $\beta$ & $P$ & $\beta$ & $P$ & $\beta$ & $P$ & $\beta$ & $P$ \\
\hline Age & .10 & .47 & .33 & .02 & .01 & .92 & -.03 & .83 & -.20 & .17 & .01 & .95 \\
\hline Children (yes/no) & .07 & .57 & .33 & .01 & .15 & .16 & -.05 & .67 & -.02 & .85 & -.03 & .85 \\
\hline Highly educated (MSc/BSc) & -.02 & .84 & -.01 & .93 & .00 & .98 & -.01 & .96 & .24 & .08 & .02 & .89 \\
\hline Middle vocational education & -.17 & .16 & .03 & .80 & .04 & .70 & .04 & .72 & -.03 & .78 & -.16 & .23 \\
\hline Cancer affected (yes/no) & .29 & .044 & -.07 & .58 & .10 & .42 & .13 & .36 & .24 & .10 & .27 & .07 \\
\hline Info needs & .06 & .61 & .18 & .11 & .07 & .48 & -.14 & .25 & .16 & .19 & .05 & .68 \\
\hline Knowledge & .05 & .70 & .22 & .08 & -.05 & .66 & -.10 & .38 & -.14 & .29 & .03 & .82 \\
\hline Breast cancer worry & -.16 & .26 & -.03 & .83 & -.13 & .31 & -.03 & .80 & -.26 & .09 & -.03 & .85 \\
\hline Anxiety & .25 & .08 & .09 & .53 & .22 & .09 & .12 & .40 & .08 & .58 & .20 & .22 \\
\hline Risk of being a mutation carrier (high/low) ${ }^{\mathrm{a}}$ & .07 & .53 & $\mathrm{NA}^{\mathrm{b}}$ & & .55 & .000 & .42 & .000 & .23 & .07 & -.04 & .75 \\
\hline Information preference (elaborate/concise) ${ }^{\mathrm{a}}$ & -.21 & .053 & -.12 & .29 & $\mathrm{NA}^{\mathrm{b}}$ & & .00 & .95 & -.23 & .04 & .02 & .85 \\
\hline Adjusted $R^{2}$ & .13 & & .04 & & .36 & & .22 & & .14 & & .02 & \\
\hline
\end{tabular}

$\beta$ beta; $N A$ not applicable

${ }^{\text {a }}$ Tailoring variable: high-risk counselees received more information

${ }^{\mathrm{b}}$ Information on these web pages was not tailored based on the tailoring variable 